This document was prepared in conjunction with work accomplished under Contract No. DE-AC09-96SR18500 with the U.S. Department of Energy.

This work was prepared under an agreement with and funded by the U.S. Government. Neither the U. S. Government or its employees, nor any of its contractors, subcontractors or their employees, makes any express or implied: 1 . warranty or assumes any legal liability for the accuracy, completeness, or for the use or results of such use of any information, product, or process disclosed; or 2 . representation that such use or results of such use would not infringe privately owned rights; or 3 . endorsement or recommendation of any specifically identified commercial product, process, or service. Any views and opinions of authors expressed in this work do not necessarily state or reflect those of the United States Government, or its contractors, or subcontractors. 
WSRC-TR-2005-00329

Revision 0

\section{Dissolution of FB-Line Metal Residues Containing Beryllium in H-Canyon}

\section{Tracy S. Rudisill, Mark L. Crowder, and Michael G. Bronikowski}

July 2005

Westinghouse Savannah River Company

Aiken, SC 29808 



\title{
Dissolution of FB-Line Metal Residues Containing Beryllium in H-Canyon
}

By

\author{
Tracy S. Rudisill, Mark L. Crowder, and Michael G. Bronikowski \\ Issued: July 2005
}

\section{Approvals}

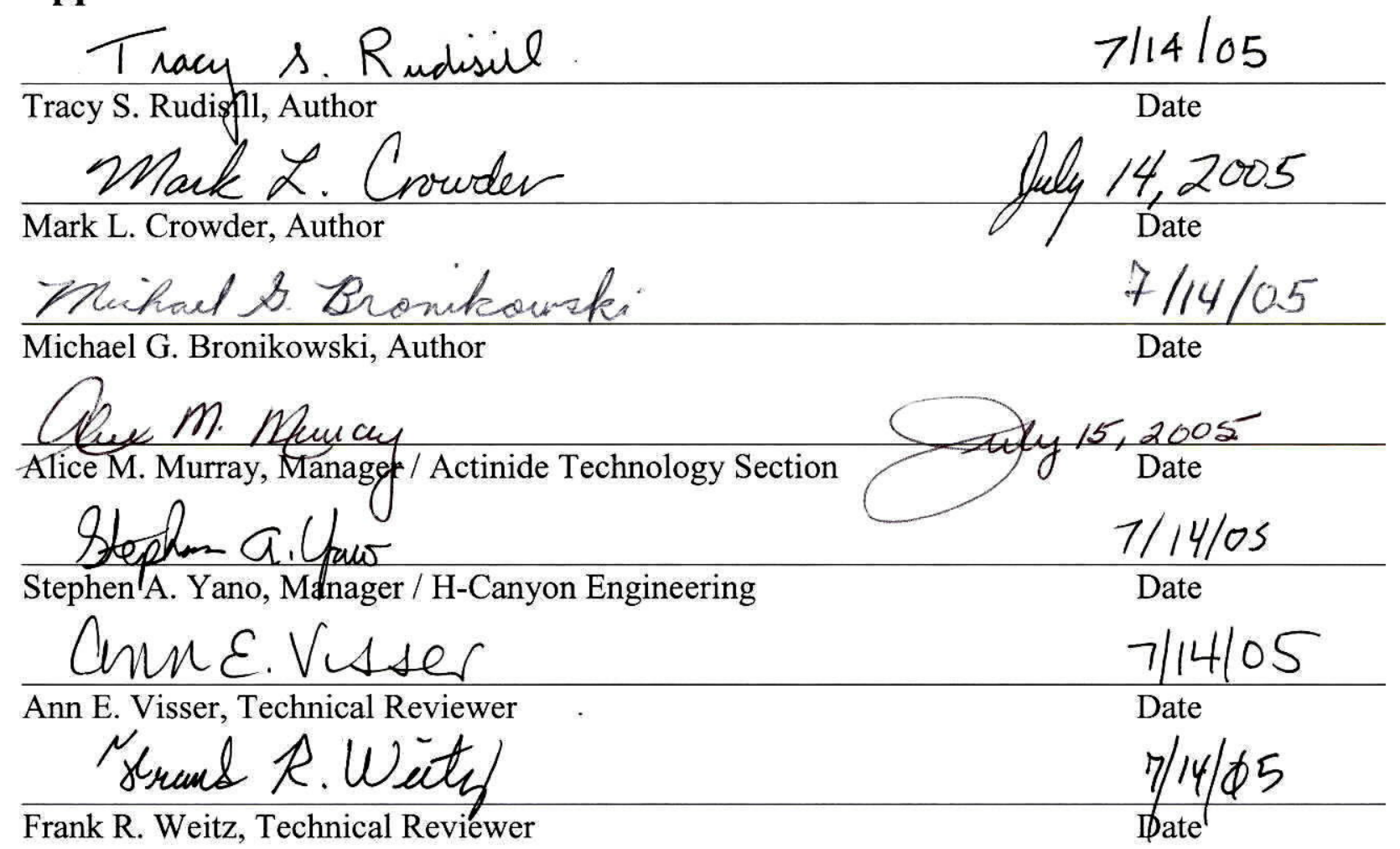


WSRC-TR-2005-00329

Revision 0

\section{This page was intentionally left blank.}




\section{Table of Contents}

Section

Summary

Introduction

Background

Proposed Flowsheet

Experimental Objectives

Experimental

Sample Preparation

Dissolver Solution

Metal Dissolution

Results and Discussion

General Observations

Solution Analysis

Solids Analysis

Conclusions

References
Page

1

3

3

3

4

5

5

5

6

7

7

8

9

11

13 


\section{List of Tables}

\section{Page}

Table $1 \quad$ Proposed H-Canyon Dissolution Flowsheet $\ldots \ldots \ldots \ldots \ldots \ldots \ldots$

Table 2 Mass of $\mathrm{Pu}$ and Be Metals Used in Flowsheet Demonstration ..... 5

Table 3 Dissolving Solution Composition $\ldots \ldots \ldots \ldots \ldots \ldots \ldots \ldots$

\section{List of Figures}

Figure $1 \quad$ Metal Dissolution Equipment $\ldots \ldots \ldots \ldots \ldots \ldots \ldots \ldots \ldots \ldots$

Figure 2 Dissolution of $\mathrm{Pu}$ and Be Metals $\ldots \ldots \ldots \ldots \ldots \ldots \ldots$

Figure 3 Concentration of B and Fe in Dissolver Solution . . . . . . . . . . 19

Figure 4 Concentration of $\mathrm{Ca}$ and $\mathrm{F}^{-}$in Dissolver Solution $\ldots \ldots \ldots 21$

Figure $5 \quad$ Micrographs of Residual Solids $\ldots \ldots \ldots \ldots \ldots \ldots \ldots \ldots \ldots \ldots$

Figure $6 \quad$ EDS for Residual Solids $\ldots \ldots \ldots \ldots \ldots \ldots \ldots \ldots \ldots \ldots \ldots$

\section{List of Appendices}

Appendix A Elemental Analyses for Flowsheet Demonstration $\ldots \ldots \ldots \ldots \ldots$

Appendix B Correction of Elemental Concentrations for Changes in Volume . . . 37 
WSRC-TR-2005-00329

Revision 0

\title{
Dissolution of FB-Line Metal Residues Containing Beryllium in H-Canyon
}

\author{
Tracy S. Rudisill, Mark L. Crowder, and Michael G. Bronikowski \\ Westinghouse Savannah River Company \\ Aiken, SC 29808
}

\section{Summary}

Scrap materials containing plutonium $(\mathrm{Pu})$ metal from FB-Line vaults are currently being dissolved in HB-Line for subsequent disposition through the H-Canyon facility. However, milestone and schedule commitments may require the dissolution of material containing $\mathrm{Pu}$ and beryllium (Be) metals in $\mathrm{H}$-Canyon. To support this option, a flowsheet for dissolving $\mathrm{Pu}$ and Be metals in $\mathrm{H}$-Canyon was demonstrated using a $4 \mathrm{M}$ nitric acid $\left(\mathrm{HNO}_{3}\right)$ solution containing $0.3 \mathrm{M}$ fluoride $\left(\mathrm{F}^{-}\right)$. The $\mathrm{F}^{-}$was added as calcium fluoride $\left(\mathrm{CaF}_{2}\right)$. The dissolving solution also contained $2.5 \mathrm{~g} / \mathrm{L}$ boron (B), a nuclear safety contingency for the H-Canyon dissolver, and $3.9 \mathrm{~g} / \mathrm{L}$ iron $(\mathrm{Fe})$ to represent the dissolution of carbon steel cans. The solution was heated to $90-95^{\circ} \mathrm{C}$ during the $8 \mathrm{~h}$ dissolution cycle.

Dissolution of the Be metal appeared to begin as soon as the samples were added to the dissolver. Clear, colorless bubbles generated on the surface were observed and were attributed primarily to the generation of hydrogen $\left(\mathrm{H}_{2}\right)$ gas. The generation of nitrogen dioxide $\left(\mathrm{NO}_{2}\right)$ gas was also evident from the color of the solution. Essentially all of the Pu and Be dissolved during the first hour of the dissolution as the solution was heated to $90-95^{\circ} \mathrm{C}$. The amount of residual solids collected following the dissolution was $<2 \%$ of the total metal charged to the dissolver. Examination of residual solids by scanning electron microscopy (SEM) showed that the largest dimension of the particles was less than $50 \mu \mathrm{m}$ with particles of smaller dimensions being more abundant. Energy dispersive spectra from spots on some of the particles showed the solids consisted of a small amount of undissolved material, corrosion products from the glassware, and dried salts from the dissolving solution. 
WSRC-TR-2005-00329

Revision 0

\section{This page was intentionally left blank.}




\section{Introduction}

\section{$\underline{\text { Background }}$}

Scrap materials containing Pu metal from FB-Line vaults are currently being dissolved in HB-Line for subsequent disposition through the H-Canyon facility. To meet milestone and schedule commitments, material containing $\mathrm{Pu}$ and Be metals may be dissolved in H-Canyon. A dissolution flowsheet similar to the flowsheets used for the dissolution of scrub alloy in $\mathrm{H}-\mathrm{Canyon}$ [1] and unirradiated Mark 42 targets in F-Canyon [2] has been proposed. In those flowsheets, high concentrations $(0.2-0.3 \mathrm{M})$ of $\mathrm{F}^{-}$with $(3$ or $8 \mathrm{M}) \mathrm{HNO}_{3}$ were required to catalyze the dissolution of $\mathrm{Pu}$ metal or oxide due to $\mathrm{F}^{-}$complexation with the boron (B). Boron was added to the dissolver as a neutron poison.

A dissolution flowsheet for composite materials containing $\mathrm{Pu}$ and Be metals was developed for Phase I of the HB-Line facility.[3] Recommendations from the development program included the use of $4 \mathrm{M} \mathrm{HNO}_{3}$ and $0.15-0.2 \mathrm{M} \mathrm{F}^{-}$for the dissolution of the metals. To dissolve this material in $\mathrm{H}$-Canyon, the use of $2.5 \mathrm{~g} / \mathrm{L} \mathrm{B}$ is required as a nuclear safety contingency. Although other metals in the $\mathrm{H}$-Canyon dissolver complex $\mathrm{F}^{-}(\mathrm{Pu}, \mathrm{Be}$, and $\mathrm{Fe}$ from carbon steel cans), B has the most significant effect on the free $\mathrm{F}^{-}$concentration. The addition of even a small amount of B significantly reduces the measured value.[4] For this reason, there was a concern that the $\mathrm{F}^{-}$ concentration recommended for the HB-Line flowsheet would be insufficient to catalyze the complete dissolution of the $\mathrm{Pu} / \mathrm{Be}$ composite material.

For the HB-Line flowsheet, the use of $4 \mathrm{M} \mathrm{HNO}_{3}$ (instead of 8-9 $\mathrm{M}$ ) was recommended for the dissolution of the composite material to reduce the formation of plutonium oxide $\left(\mathrm{PuO}_{2}\right)$ on the surface. In a highly oxidizing solution, the surface of $\mathrm{Pu}$ metal passivates by forming a thin layer of $\mathrm{PuO}_{2}$. For this reason, $\mathrm{F}^{-}$is added to the dissolving solution to catalyze the dissolution of the $\mathrm{PuO}_{2}$. If insufficient free $\mathrm{F}^{-}$is available to dissolve the oxide, solids will accumulate in the dissolving vessel. Although $\mathrm{B}$ will be added to the H-Canyon dissolving solution as a nuclear safety contingency to accommodate a limited amount of insoluble fissile solids, subsequent charges of material to the same solution cannot be made if too much insoluble fissile solids accumulate in the dissolver.

\section{Proposed Flowsheet}

To address criticality constraints, the use of eight sequential charges in a $7200 \mathrm{~L}$ batch was proposed for the dissolution of the $\mathrm{Pu} / \mathrm{Be}$ composite material in $\mathrm{H}$-Canyon. The total mass of $\mathrm{Pu}$ and Be to dissolve and the final calculated concentrations in the solution are shown in Table 1. Each charge of material will be added to the dissolver in two carbon steel cans. The estimated Fe from the cans which must be dissolved and the final calculated concentration is also shown in the table. 
WSRC-TR-2005-00329

Revision 0

Table 1 Proposed H-Canyon Dissolution Flowsheet 1

\begin{tabular}{|c|c|c|c|}
\hline \multirow[t]{2}{*}{ Component } & \multirow{2}{*}{$\begin{array}{c}\text { Total Mass } \\
(\mathrm{g})\end{array}$} & \multicolumn{2}{|c|}{ Concentration } \\
\hline & & $(\mathrm{g} / \mathrm{L})$ & $(\mathrm{M})$ \\
\hline Dissolved Material & & \multicolumn{2}{|c|}{ Final Value } \\
\hline $\mathrm{Pu}$ & 4,530 & 0.63 & 0.0026 \\
\hline $\mathrm{Be}$ & 870 & 0.12 & 0.013 \\
\hline $\mathrm{Fe}$ & 26,400 & 3.67 & 0.066 \\
\hline Dissolving Solution & & \multicolumn{2}{|c|}{ Initial Value } \\
\hline $\mathrm{HNO}_{3}$ & & & 4 \\
\hline $\mathrm{F}^{-}$ & & & 0.3 \\
\hline $\mathrm{B}$ & & 2.5 & 0.23 \\
\hline
\end{tabular}

To dissolve the $\mathrm{Pu}, \mathrm{Be}$, and carbon steel cans in the presence of $2.5 \mathrm{~g} / \mathrm{L} \mathrm{B}$, the use of a $4 \mathrm{M}$ $\mathrm{HNO}_{3}$ solution containing $0.3 \mathrm{M} \mathrm{F}^{-}$was proposed (Table 1). Calcium fluoride will be used as the $\mathrm{F}^{-}$source. The use of $\mathrm{CaF}_{2}$ has the advantage that higher $\mathrm{F}^{-}$concentrations can be used without concern about the precipitation of boron salts, as is the case with potassium fluoride.[2] A dissolution temperature of $90-95^{\circ} \mathrm{C}$ was also proposed.

\section{Experimental Objectives}

To confirm that the $\mathrm{Pu} / \mathrm{Be}$ composite material can be readily dissolved in $\mathrm{H}$-Canyon without the generation of excessive amounts of Pu-containing solids, a demonstration of the proposed flowsheet was performed. During the demonstration, scrap Pu and contaminated Be metals from the FB-Line facility were dissolved using a solution of approximately the same concentrations as given in Table 1. Iron was added to the dissolving solution as soluble ferric nitrate nonahydrate $\left(\mathrm{Fe}\left(\mathrm{NO}_{3}\right)_{3} \cdot 9 \mathrm{H}_{2} \mathrm{O}\right)$ based on the concentration listed in the table. The presence of Fe is not expected to significantly change the dissolution chemistry. Throughout the dissolution, samples of the dissolving solution were removed for analysis to follow the concentrations of $\mathrm{Pu}, \mathrm{Be}$, and other elements of interest as functions of time. Once the dissolution cycle was complete, the solution was filtered to collect and measure the mass of undissolved solids. A sample of the residual solids was analyzed by SEM to identify the elemental constituents of the material. 


\section{Experimental}

\section{Sample Preparation}

The demonstration of the $\mathrm{Pu}$ and $\mathrm{Be}$ metal dissolution flowsheet was performed using one liter of solution. At this scale, the mass of $\mathrm{Pu}$ and $\mathrm{Be}$ required to achieve the final concentrations given in Table 1 are 0.63 and $0.12 \mathrm{~g}$, respectively. Since dividing these small amounts of metal into eight equal charges for sequential dissolution would be extremely difficult, the demonstration was performed by adding all of the $\mathrm{Pu}$ and $\mathrm{Be}$ metal to the dissolver at one time.

To perform the demonstration, scrap $\mathrm{Pu}$ and contaminated Be metals obtained from the FB-Line facility were used as the feed material. Larger pieces of metal were broken to the desired mass using a pair of pliers. The mass of each material used in the demonstration and the final calculated concentration in one liter of solution are listed in Table 2.

Table 2 Mass of $\mathrm{Pu}$ and Be Metals Used in Flowsheet Demonstration

\begin{tabular}{cccc}
\hline \hline Component & Total Mass & \multicolumn{2}{c}{ Concentration } \\
& $(\mathrm{g})$ & $(\mathrm{g} / \mathrm{L})$ & $(\mathrm{M})$ \\
\hline $\mathrm{Pu}$ & 0.9957 & 1.0 & 0.0042 \\
$\mathrm{Be}$ & 0.1362 & 0.14 & 0.015 \\
\hline
\end{tabular}

\section{$\underline{\text { Dissolver Solution }}$}

The dissolver solution for the flowsheet demonstration was prepared by initially diluting concentrated $(15.7 \mathrm{M}) \mathrm{HNO}_{3}$ with deionized water to obtain nominally $900 \mathrm{~mL}$ of $4-5 \mathrm{M}$ acid. Sufficient boric acid $\left(\mathrm{H}_{3} \mathrm{BO}_{3}\right)$ was added to obtain a concentration of $2.5 \mathrm{~g} / \mathrm{L}$ once the solution was diluted to volume. Appropriate amounts of $\mathrm{CaF}_{2}$ and $\mathrm{Fe}\left(\mathrm{NO}_{3}\right)_{3} \cdot 9 \mathrm{H}_{2} \mathrm{O}$ were then dissolved to obtain nominally the same concentrations given in Table 1 (following dilution to a one liter volume). The resulting solution was then transferred to a one liter volumetric flask which was diluted to volume with deionized water. The composition of the resulting solution is given in Table 3.

Table 3 Dissolving Solution Composition

\begin{tabular}{cccc}
\hline \hline Component & Mass & \multicolumn{2}{c}{ Concentration } \\
& $(\mathrm{g})$ & $(\mathrm{g} / \mathrm{L})$ & $(\mathrm{M})$ \\
\hline $\mathrm{HNO}_{3}$ & & & 4.0 \\
$\mathrm{~F}^{-}$ & & 0.30 \\
$\mathrm{~B}$ & 2.5 & 0.23 \\
$\mathrm{Fe}$ & 3.9 & 0.070 \\
\hline
\end{tabular}




\section{$\underline{\text { Metal Dissolution }}$}

The flowsheet demonstration was performed in a $1000 \mathrm{~mL}$ three-neck flask using a porous glass basket attached to the center stopper to hold and allow access to the metal samples. Prototypical equipment is shown on Figure 1. A water-cooled condenser was attached to the flask to reduce the evaporation of the dissolving solution. The solution was heated and stirred using a heating mantle equipped with a magnetic stirrer. The temperature of the solution was monitored using an alcohol-filled thermometer.

To perform the demonstration, the samples of $\mathrm{Pu}$ and $\mathrm{Be}$ metal were placed in the glass dissolving basket (see Figure 1). The metal pieces were similar in size and were about twice as large as the (nominally $5 \mathrm{~mm}$ diameter) holes in the basket. The basket was then charged to the vessel containing one liter of the dissolving solution. A magnetic stirrer was used to agitate the solution. The solution was heated to $90-95^{\circ} \mathrm{C}$, and was continuously heated and stirred for $8 \mathrm{~h}$. During the dissolution, samples of the solution were removed from the dissolver at one hour intervals. The solution was removed using a $10 \mathrm{~cm}^{3}$ plastic syringe attached to a piece of plastic tubing. The tubing was removed from the syringe and $1 \mathrm{~mL}$ aliquots of solution were expelled through $0.45 \mu \mathrm{m}$ filter disks into premarked sample vials for analysis. Excess solution was returned to the dissolver.

The samples were analyzed for Pu by liquid scintillation counting; a gamma pulse height analysis (GPHA) was used to correct the alpha activity for americium-241 $\left({ }^{241} \mathrm{Am}\right)$. Beryllium was analyzed by inductively coupled plasma - emission spectroscopy (ICP-ES). The ICP-ES analysis also provided concentration values for $\mathrm{B}, \mathrm{Fe}$, and $\mathrm{Ca}$ (and other metal impurities), although significant changes in these concentrations were not expected over the course of the dissolution. The total fluoride concentration was measured by ion chromatography (IC) at the beginning, middle, and end of the demonstration.

After the $8 \mathrm{~h}$ dissolution cycle was complete, the heating mantle and stirrer were turned off. The following day, the solution was filtered using a borosilicate membrane filter with a $0.7 \mu \mathrm{m}$ pore size. The mass of the membrane filter was measured prior to the filtration to allow calculation of the amount of solids which were collected. The membrane filter and solids were allowed to dry for approximately 4 days before the final mass was measured. A sample of the filter paper was analyzed by scanning electron microscopy to identify the composition of the solids. 


\section{Results and Discussion}

\section{$\underline{\text { General Observations }}$}

When the Pu and Be metals were charged to the dissolver, the generation of clear, colorless bubbles on the surface of the Be metal appeared to begin almost immediately. Wisps of brown solution were also seen near the surface of the same piece of metal. Based on the observations and gas analyses performed during the development of the dissolution flowsheet for FB-Line residues containing Be metal, the majority of the clear, colorless bubbles was most likely hydrogen $\left(\mathrm{H}_{2}\right)$ generated during the dissolution of Be by a metal-acid dissolution mechanism (equation 1).

$$
\mathrm{Be}+2 \mathrm{HNO}_{3} \rightarrow \mathrm{Be}\left(\mathrm{NO}_{3}\right)_{2}+\mathrm{H}_{2}
$$

Beryllium also dissolves by nitrate oxidation to produce nitric oxide (NO) and nitrous oxide $\left(\mathrm{N}_{2} \mathrm{O}\right)$ which are both colorless gases (equations 2-3); however, at room temperature, the metal-acid dissolution mechanism predominates.[3]

$$
\begin{aligned}
& 3 \mathrm{Be}+8 \mathrm{HNO}_{3} \rightarrow 3 \mathrm{Be}\left(\mathrm{NO}_{3}\right)_{2}+2 \mathrm{NO}+4 \mathrm{H}_{2} \mathrm{O} \\
& 4 \mathrm{Be}+10 \mathrm{HNO}_{3} \rightarrow 4 \mathrm{Be}\left(\mathrm{NO}_{3}\right)_{2}+\mathrm{N}_{2} \mathrm{O}+5 \mathrm{H}_{2} \mathrm{O}
\end{aligned}
$$

The wisps of brown solution were evidence of the production of $\mathrm{NO}_{2}$ by a nitrate oxidation mechanism (equation 4).

$$
\mathrm{Be}+4 \mathrm{HNO}_{3} \rightarrow \mathrm{Be}\left(\mathrm{NO}_{3}\right)_{2}+2 \mathrm{NO}_{2}+2 \mathrm{H}_{2} \mathrm{O}
$$

The dissolution of $\mathrm{Pu}$ metal in a $\mathrm{HNO}_{3}$ solution containing $\mathrm{F}^{-}$also produces $\mathrm{H}_{2}$ and nitrogencontaining gases; [3] although, the volume of gas produced per mass of material dissolved is significantly less than $\mathrm{Be}$ due to the much higher molecular weight of $\mathrm{Pu}$.

The temperature of the dissolving solution was gradually increased from room temperature to $90-95^{\circ} \mathrm{C}$ over approximately one hour. During this time, the colorless solution became pale yellow in color, indicative of soluble $\mathrm{NO}_{2}$ gas and perhaps the dissolved $\mathrm{Pu}$. The first samples of the solution were removed from the dissolver one hour after heating began. When sampling was complete, the glass basket was removed from the dissolver to inspect the metal pieces. No metal was present in the basket. Only a few black specks could be seen on the bottom of the basket. Although small metal slivers could have easily slipped through the holes in the basket into the bulk solution, no solid material could be seen in the dissolver. Inspection of the solution was somewhat obscured by the heating mantle and yellow-brown color of the solution; however, the solution appeared homogenous, even when viewed with the light from a flashlight. After the $8 \mathrm{~h}$ heating cycle was complete, the heating mantle and stirrer were turned off. The following day, no solids were visible in the solution. 


\section{$\underline{\text { Solution Analysis }}$}

The radiochemical, ICP-ES, and IC analyses for the samples generated during the dissolution of the $\mathrm{Pu}$ and $\mathrm{Be}$ metals are shown in Appendix A. Before the concentrations were correlated with the dissolution time, they were corrected for the small change in volume which occurred as a result of sample removal and evaporation losses; although a small concentrating effect would be expected in the H-Canyon dissolver due to evaporation. A small correction was also made for the amount of material removed in samples prior to completing the experiment. The magnitude of the corrections ranged from $<1$ to $4 \%$. The procedure used to correct the concentrations and the calculated values are presented in Appendix B.

The corrected $\mathrm{Pu}$ and $\mathrm{Be}$ concentrations as functions of the dissolution time are plotted on Figure 2. The plots show that both metals dissolved in less than one hour. The corrected concentrations in subsequent samples are essentially unchanged. The analytical results are consistent with the observation that solids were not seen in the dissolution vessel beyond the time when the first samples were removed. The corrected concentrations for $\mathrm{Pu}$ and $\mathrm{Be}$ also agree well with the concentrations expected based on the amounts of metal charged to the dissolver (see Table 2).

Corrected concentrations for the B and Fe in the solution are plotted on Figure 3 as functions of the dissolution time. As expected, the concentration of each element was essentially constant throughout the dissolution. The corrected concentrations from the ICP-ES analysis agree reasonably well with the concentrations calculated from the masses of $\mathrm{H}_{3} \mathrm{BO}_{3}$ and $\mathrm{Fe}\left(\mathrm{NO}_{3}\right)_{3} \bullet 9 \mathrm{H}_{2} \mathrm{O}$ added during the preparation of the dissolving solution. The average $\mathrm{B}$ and $\mathrm{Fe}$ concentrations from the analysis were $2.35 \pm 0.02$ and $3.80 \pm 0.04 \mathrm{~g} / \mathrm{L}(95 \%$ confidence) compared to target concentrations of 2.5 and $3.9 \mathrm{~g} / \mathrm{L}$, respectively. The low biases (nominally 6 and $3 \%$ ) could be attributed to moisture in the reagent or perhaps spectral interferences during the analysis. However, even if the measured values are accurate, a slight reduction in either concentration in the dissolving solution would not change the conclusion that both $\mathrm{Pu}$ and $\mathrm{Be}$ dissolve in less than nominally one hour using the proposed flowsheet.

The corrected concentrations for the $\mathrm{F}^{-}$and $\mathrm{Ca}$ in the dissolving solution are plotted on Figure 4 as functions of the dissolution time. Again, as expected, the concentrations were essentially constant throughout the dissolution. However, the corrected concentration of each element was biased low compared to the amount of $\mathrm{CaF}_{2}$ added during the preparation of the dissolving solution. The average $\mathrm{F}^{-}$concentration was $0.19 \pm 0.01 \mathrm{M}(95 \%$ confidence) compared to the target value of $0.3 \mathrm{M}$. The substantial difference in the two values was attributed to the presence of elements $(\mathrm{Pu}, \mathrm{B}, \mathrm{Fe}$, and $\mathrm{Ca})$ which complex $\mathrm{F}^{-}$and lower the concentration measured by the $\mathrm{IC}$ analysis. The low bias in the IC analysis is evident from the corrected Ca concentrations. The average Ca value during the dissolution was $0.13 \pm 0.002 \mathrm{M}$ (95\% confidence) compared to the target value of $0.15 \mathrm{M}$. The stoichiometry of $\mathrm{CaF}_{2}$ indicates that the $\mathrm{F}^{-}$concentration should be at least $0.26 \mathrm{M}$ based on this analysis. Therefore, it appears that the actual $\mathrm{F}^{-}$concentration was between 0.26 and $0.3 \mathrm{M}$, which was sufficient to catalyze the Pu metal dissolution in less than one hour. 


\section{$\underline{\text { Solids Analysis }}$}

Following the dissolution, the solution was filtered using a borosilicate membrane filter with a $0.7 \mu \mathrm{m}$ pore size. The mass of the membrane filter was measured prior to use to allow calculation of the amount of solids which were collected. When the filter paper was inspected, only a small amount of very fine solids was seen. It appeared that complete dissolution of the $\mathrm{Pu}$ and Be metals was essentially achieved. Following the filtration, the membrane was rinsed with deionized water to remove dissolved salts. The filter paper was allowed to dry for four days. The increase in mass of the filter paper was nominally $0.02 \mathrm{~g}$. A sample of the filter paper was examined by SEM. The micrographs of the residual solids are shown on Figure 5. The images were obtained using a quadropole back scattering electron (QBSE) detector. The QBSE micrographs are indicative of the relative atomic number, where the brighter areas of the images correspond to materials with higher atomic numbers. The micrographs show that the largest dimension of the particles examined was less than approximately $50 \mu \mathrm{m}$ with particles of smaller dimensions being more abundant.

Energy dispersive spectra (EDS) were obtained to identify the elemental composition of spots on some of the particles. The spots are shown on micrographs $b$ and $c$ (Figure 5) and the corresponding EDS are shown on Figure 6. Many of the particles which were examined contained $\mathrm{Pu}$; although, the absolute mass was small based on the amount of residual solids which were recovered. Other elements $(\mathrm{Fe}, \mathrm{K}, \mathrm{F}$, and $\mathrm{Ca}$ ) in the dissolving solution were also identified in the particles. The presence of $\mathrm{Be}$ and $\mathrm{B}$ cannot be detected by the microscope due to the low atomic numbers. A number of other trace elements were also detected. In general the solids were composed of a small amount of the original undissolved material, corrosion products from the glassware, and dried salts from the dissolving solution. 
WSRC-TR-2005-00329

Revision 0

\section{This page was intentionally left blank.}




\section{Conclusions}

A flowsheet demonstration confirmed that a $\mathrm{Pu} / \mathrm{Be}$ composite material can be dissolved in $\mathrm{H}$-Canyon without the generation of excessive amounts of Pu-containing solids. Samples of $\mathrm{Pu}$ and Be metal were dissolved in $1 \mathrm{~L}$ of $4 \mathrm{M} \mathrm{HNO}_{3}$ containing $0.3 \mathrm{M} \mathrm{F}^{-}$to achieve concentrations representative of those expected in $\mathrm{H}$-Canyon. The dissolver solution contained nominally $2.5 \mathrm{~g} / \mathrm{L} \mathrm{B}$, a nuclear safety contingency in the H-Canyon dissolver, and $3.9 \mathrm{~g} / \mathrm{L}$ Fe to represent the dissolution of carbon steel cans. Dissolution of the Be metal appeared to begin as soon as the samples were added to the dissolver. Clear, colorless bubbles generated on the surface were observed and were attributed primarily to the generation of $\mathrm{H}_{2}$ gas. Essentially all of the $\mathrm{Pu}$ and Be dissolved during the first hour of an $8 \mathrm{~h}$ dissolution cycle as the solution was heated to 90$95^{\circ} \mathrm{C}$. The amount of residual solids collected following the dissolution was $<2 \%$ of the total metal charged to the dissolver. Examination of residual solids by SEM showed that the largest dimension of the particles was less than $50 \mu \mathrm{m}$ with particles of smaller dimensions being more abundant. Energy dispersive spectra from spots on some of the particles showed the solids consisted of a small amount of undissolved material, corrosion products from the glassware, and dried salts from the dissolving solution. 
WSRC-TR-2005-00329

Revision 0

\section{This page was intentionally left blank.}




\section{References}

1. R. A. Pierce, "Dissolution of Plutonium Scrub Alloy and Anode Heel Materials in H-Canyon," WSRC-TR-2003-00276, Westinghouse Savannah River Company, Aiken, SC (2003).

2. A. M. Murray and W. J. Crooks, "Flow Sheet Development for the Dissolution of Unirradiated Mark 42 Fuel Tubes in F-Canyon, Part II," WSRC-TR-99-00196, Westinghouse Savannah River Company, Aiken, SC (1999).

3. T. S. Rudisill and M. L. Crowder, WSRC-TR-2005-00042, "Dissolution of FB-Line Residues Containing Beryllium Metal," Westinghouse Savannah River Company, Aiken, SC, (2005).

4. D. G. Karraker, T. S. Rudisill, F. R. Graham, A. M. Murray, J. I. Mickalonis, J. H. Gray, R. R. Livingston, E. A. Kyser, III, R. A. Pierce, and D. B. Allen, "Flowsheet Modifications for Dissolution of Sand, Slag, and Crucible Residues in the F-Canyon Dissolvers," WSRC-TR-97-00395, Westinghouse Savannah River Company, Aiken, SC, (1997).

5. M. L. Crowder, “Dissolution of FB-Line Cabinet Sweepings,” WSRC-TR-2004-00634, Westinghouse Savannah River Company, Aiken, SC (2005). 
WSRC-TR-2005-00329

Revision 0

\section{This page was intentionally left blank.}


Figure 1 Metal Dissolution Equipment

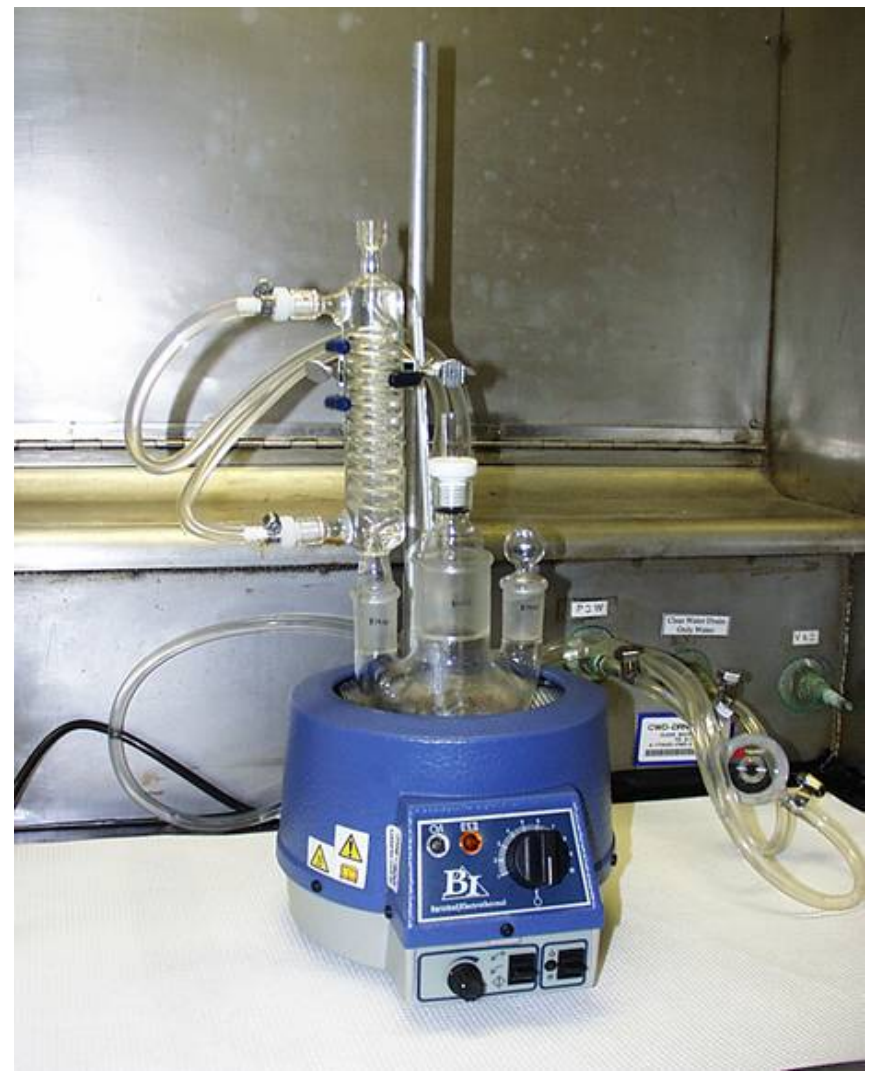

Heating Mantle and Dissolution Vessel

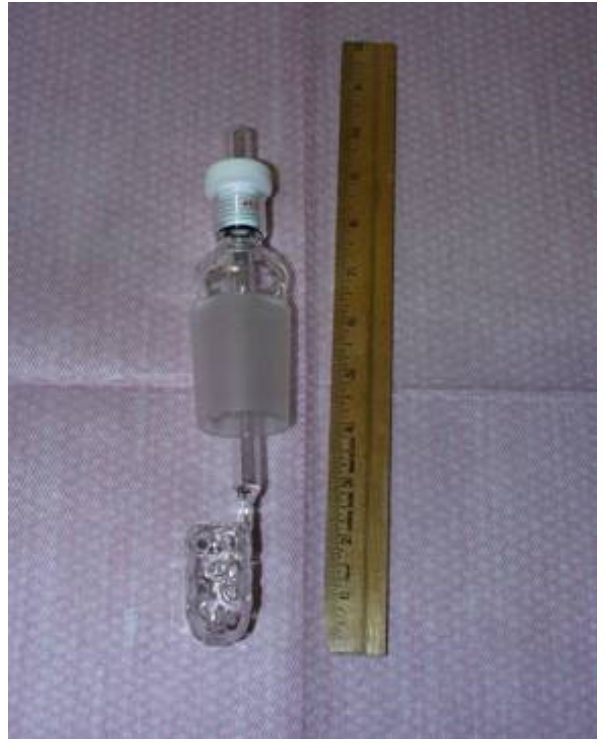

Glass Dissolving Basket 
WSRC-TR-2005-00329

Revision 0

\section{This page was intentionally left blank.}


Figure 2 Dissolution of $\mathrm{Pu}$ and Be Metals

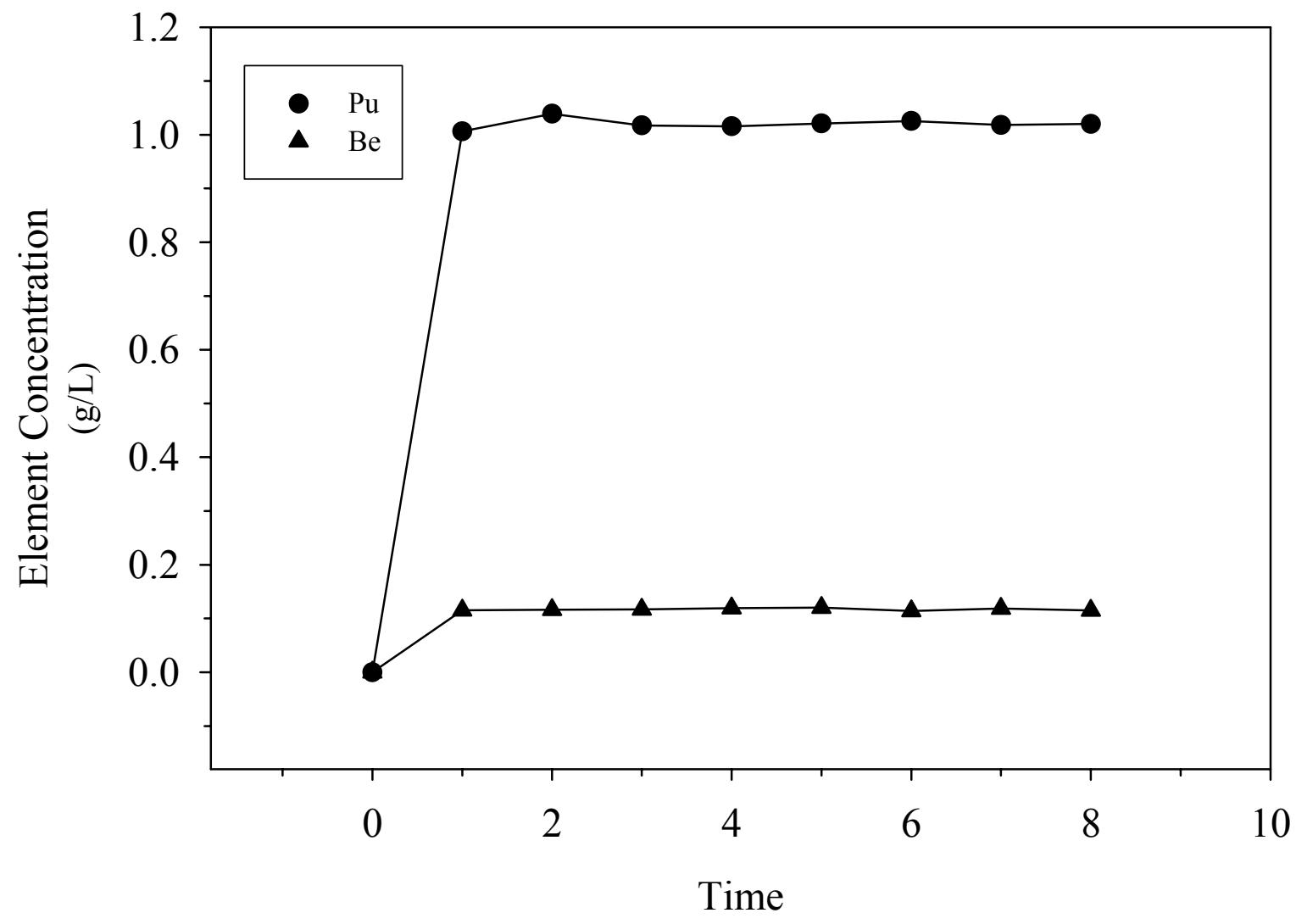

(h) 
WSRC-TR-2005-00329

Revision 0

\section{This page was intentionally left blank.}


WSRC-TR-2005-00329

Revision 0

Figure 3 Concentration of B and Fe in Dissolver Solution

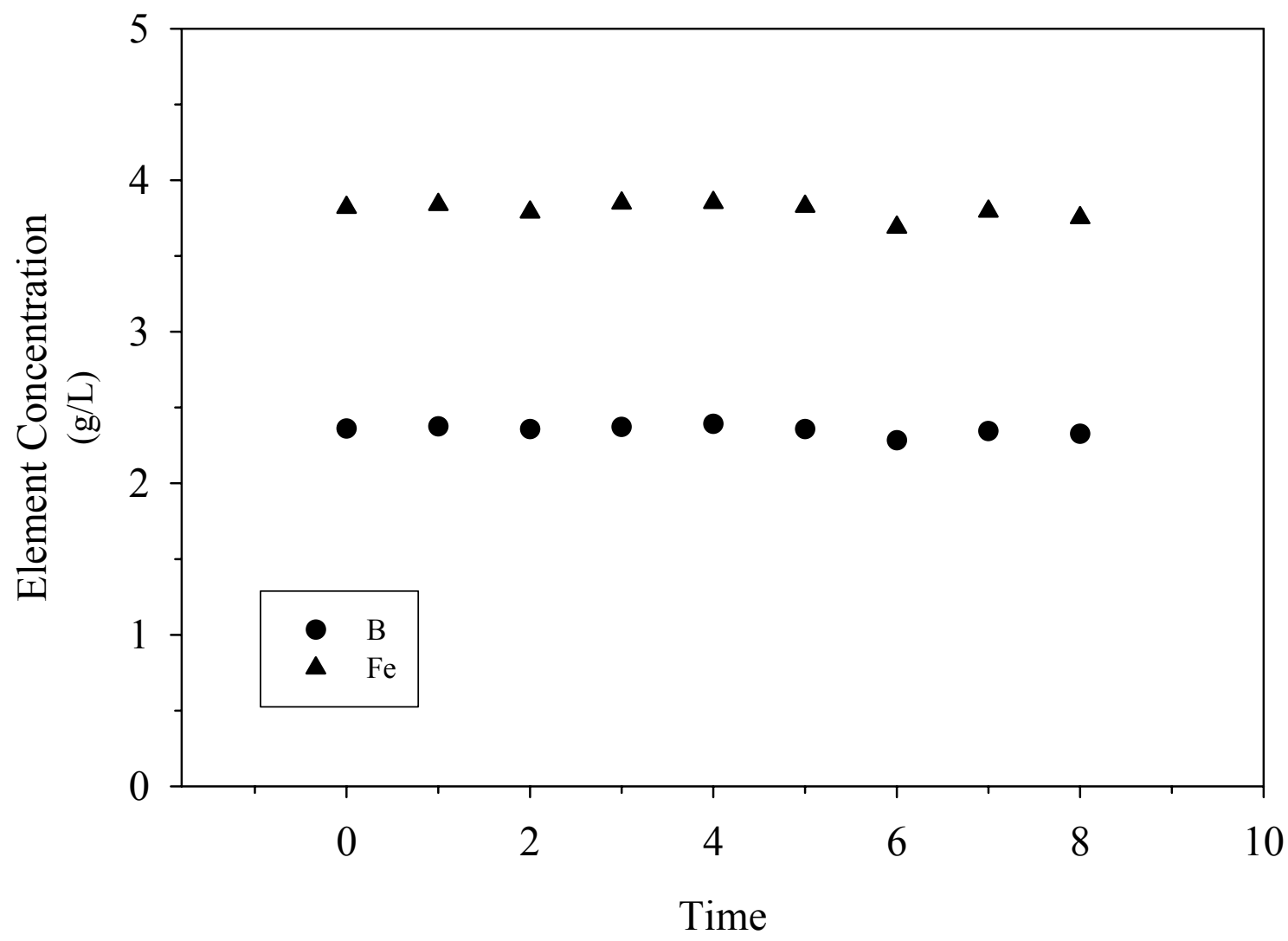

(h) 
WSRC-TR-2005-00329

Revision 0

\section{This page was intentionally left blank.}


WSRC-TR-2005-00329

Revision 0

Figure 4 Concentration of $\mathrm{Ca}$ and $\mathrm{F}^{-}$in Dissolver Solution

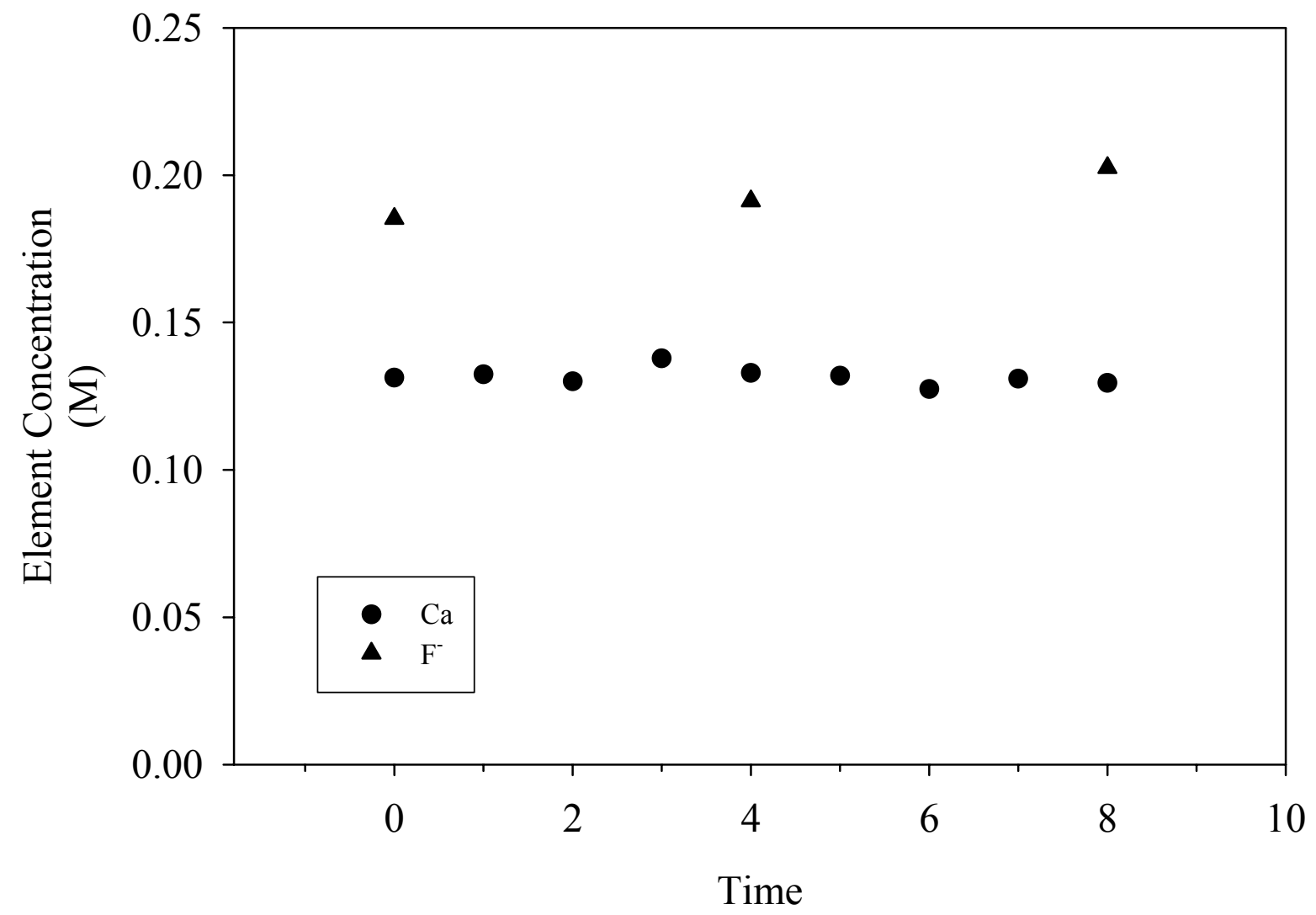

(h) 
WSRC-TR-2005-00329

Revision 0

\section{This page was intentionally left blank.}


WSRC-TR-2005-00329

Revision 0

Figure 5 Micrographs of Residual Solids

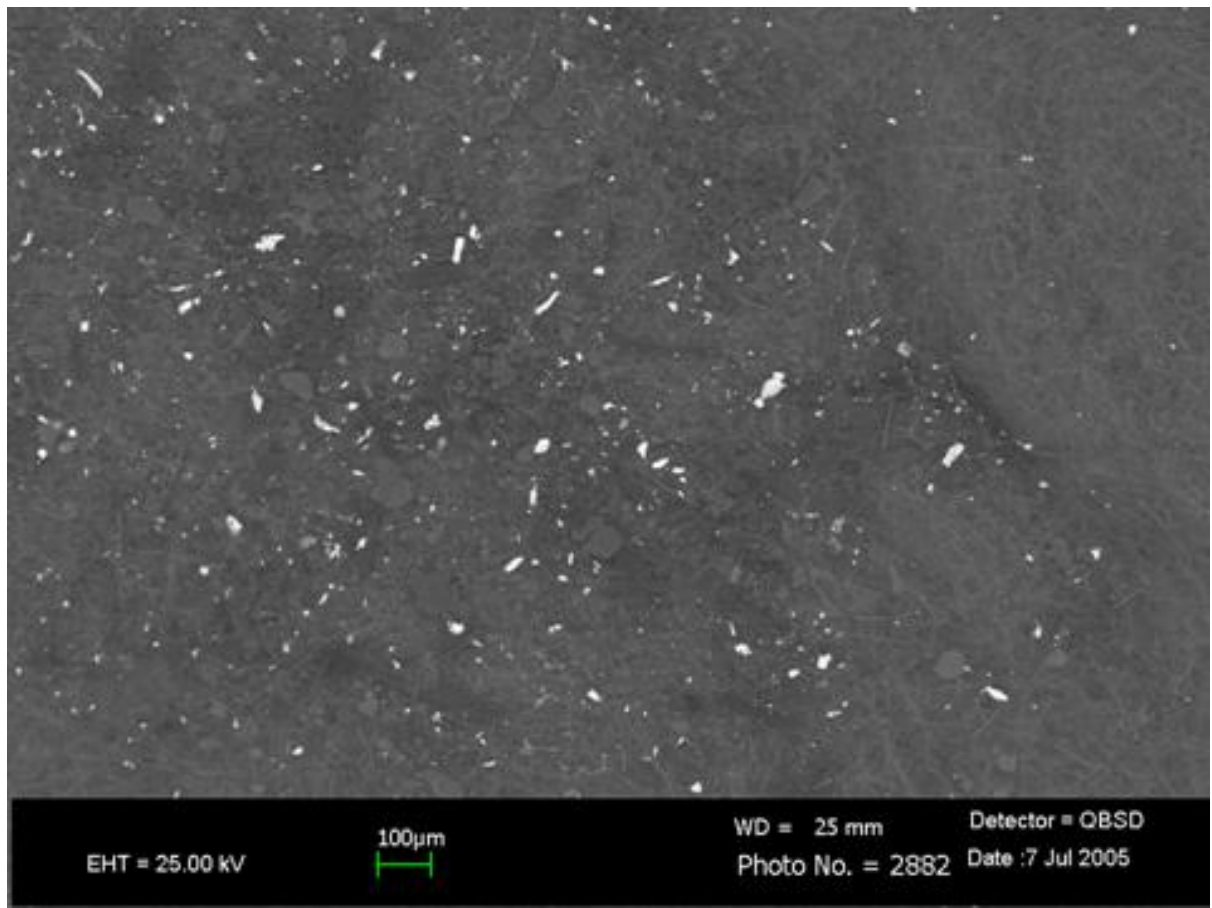

(a) Magnification 50X

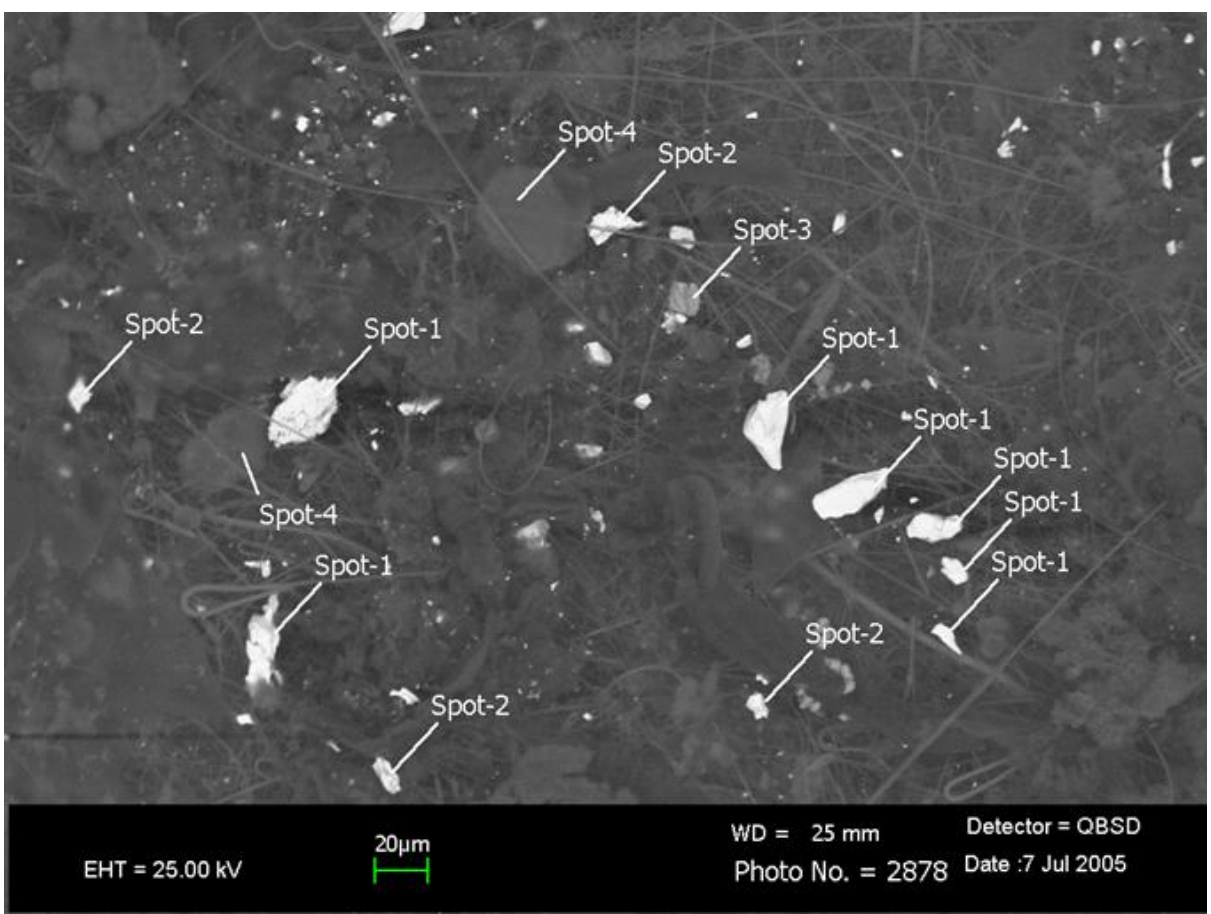

(b) Magnification 250X 
WSRC-TR-2005-00329

Revision 0

\section{This page was intentionally left blank.}


WSRC-TR-2005-00329

Revision 0

Figure 5 Continued

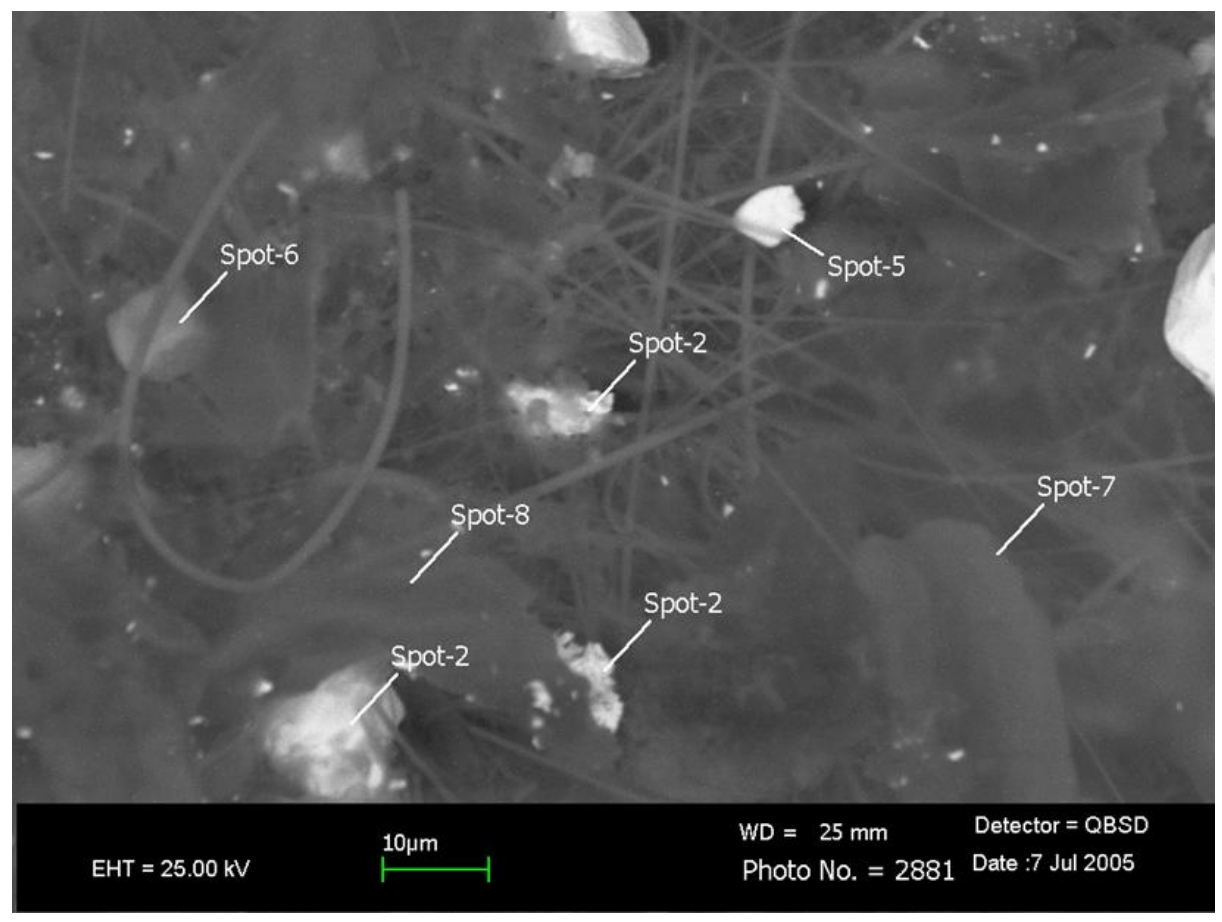

(c) Magnification 1000X 
WSRC-TR-2005-00329

Revision 0

\section{This page was intentionally left blank.}


WSRC-TR-2005-00329

Revision 0

Figure 6 EDS for Residual Solids

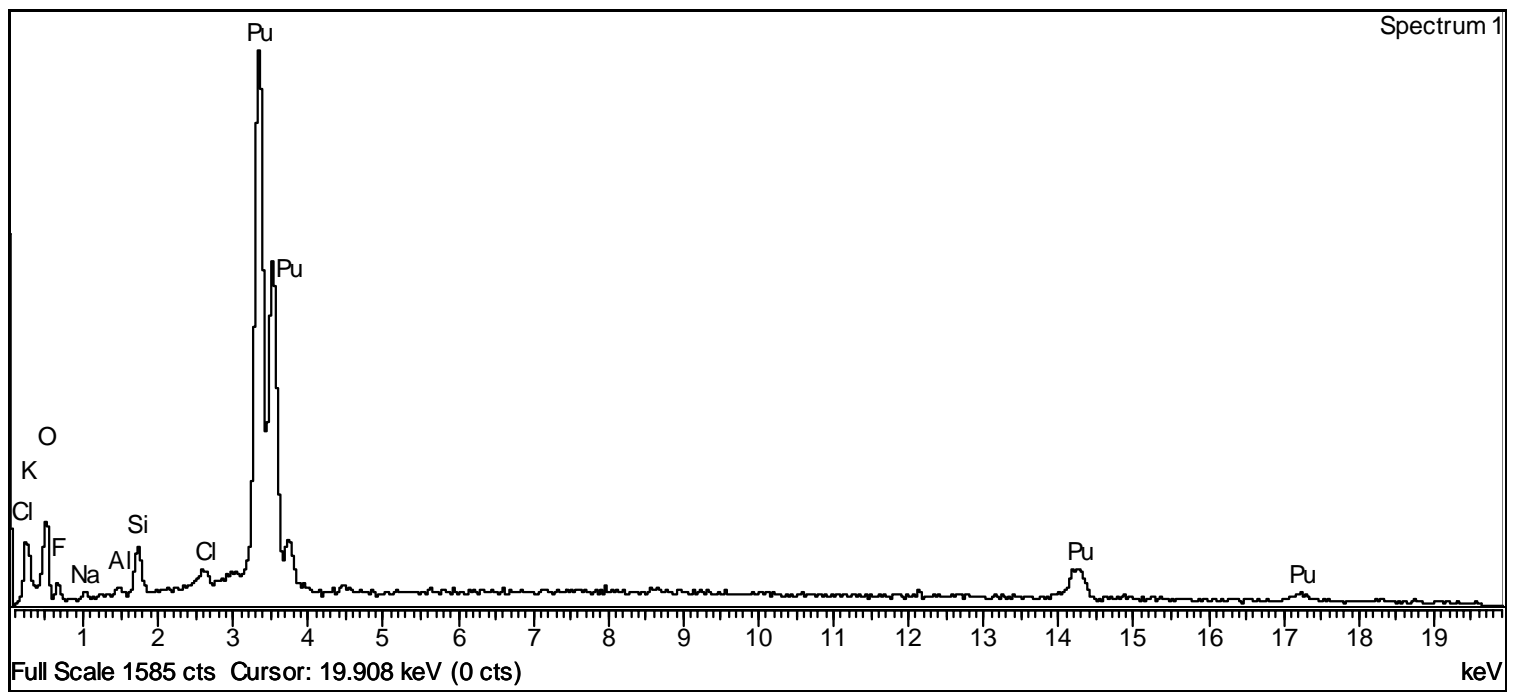

(a) Spectrum 1 (Spot 1)

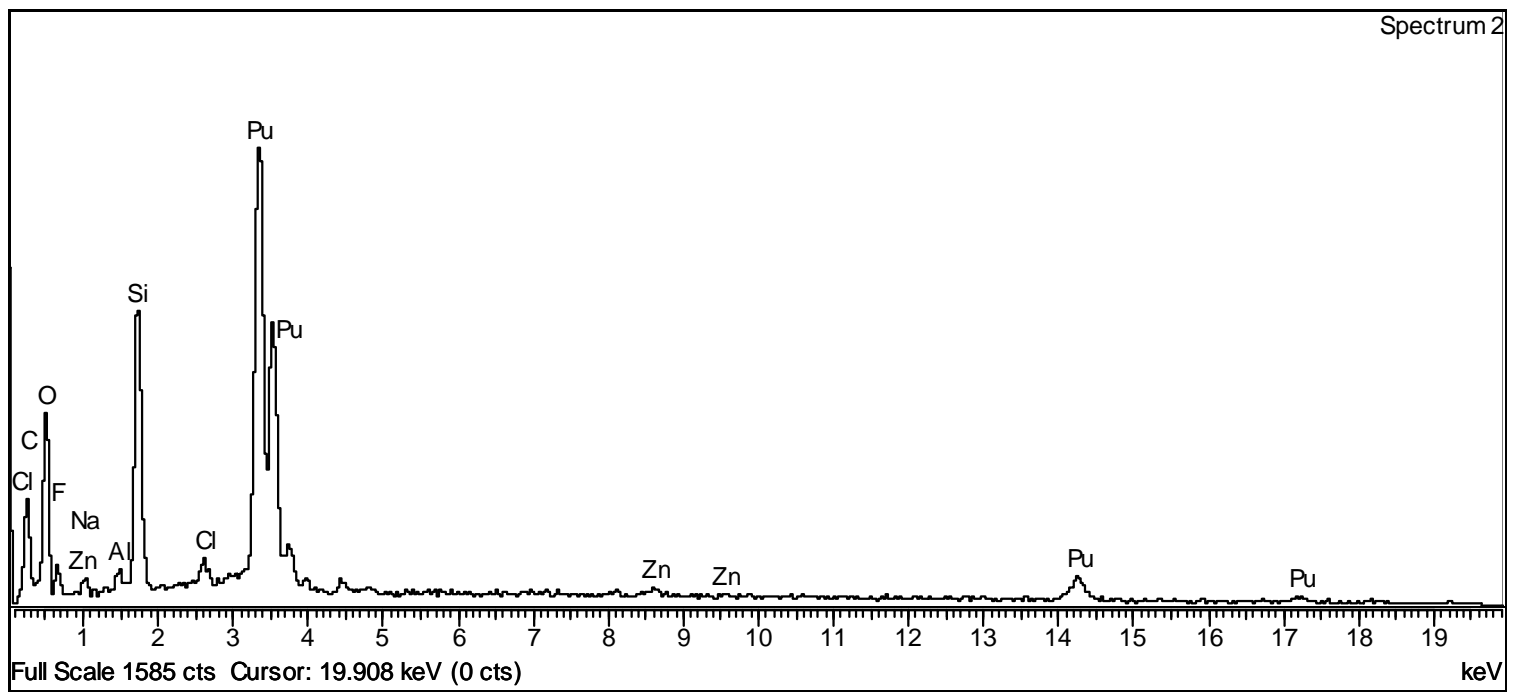

(b) Spectrum 2 (Spot 2) 
WSRC-TR-2005-00329

Revision 0

\section{This page was intentionally left blank.}


WSRC-TR-2005-00329

Revision 0

Figure 6 Continued

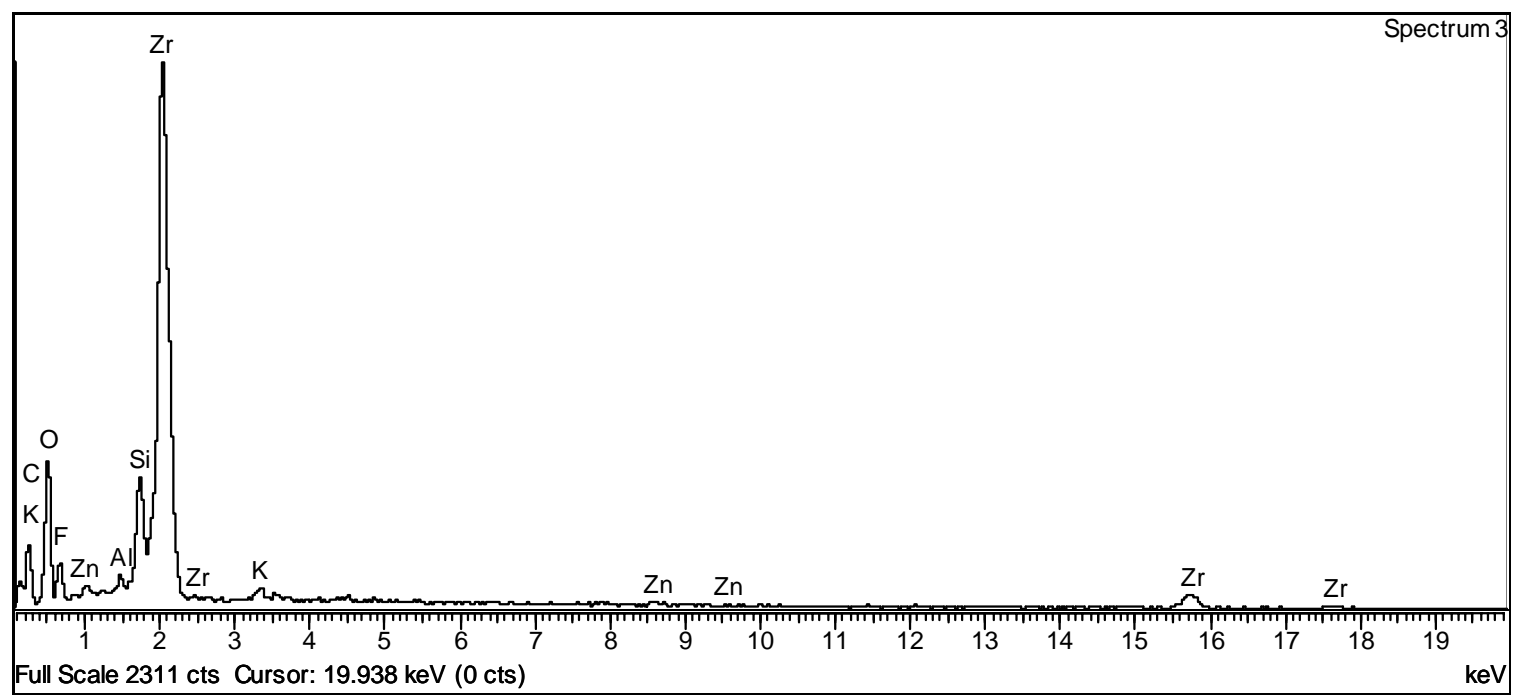

(c) Spectrum 3 (Spot 3)

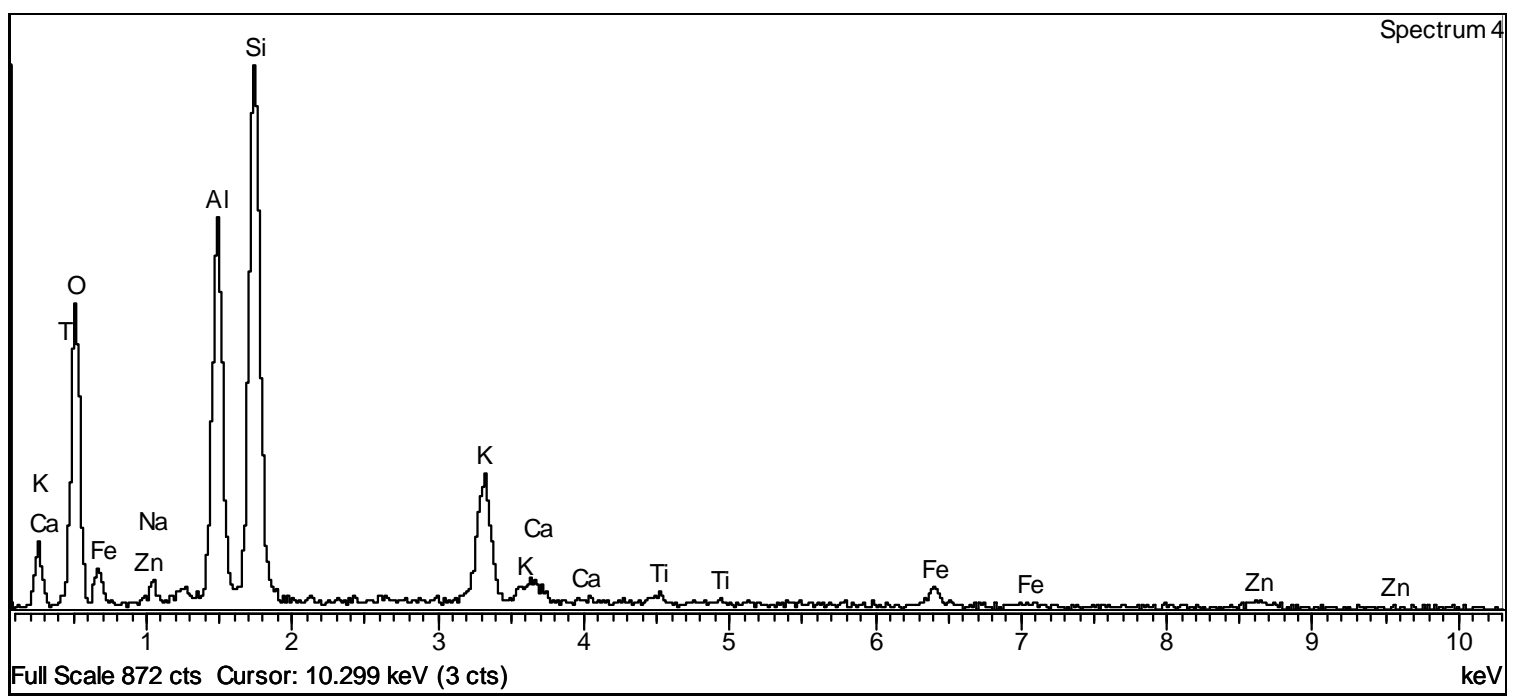

(d) Spectrum 4 (Spot 4) 
WSRC-TR-2005-00329

Revision 0

\section{This page was intentionally left blank.}


WSRC-TR-2005-00329

Revision 0

Figure 6 Continued

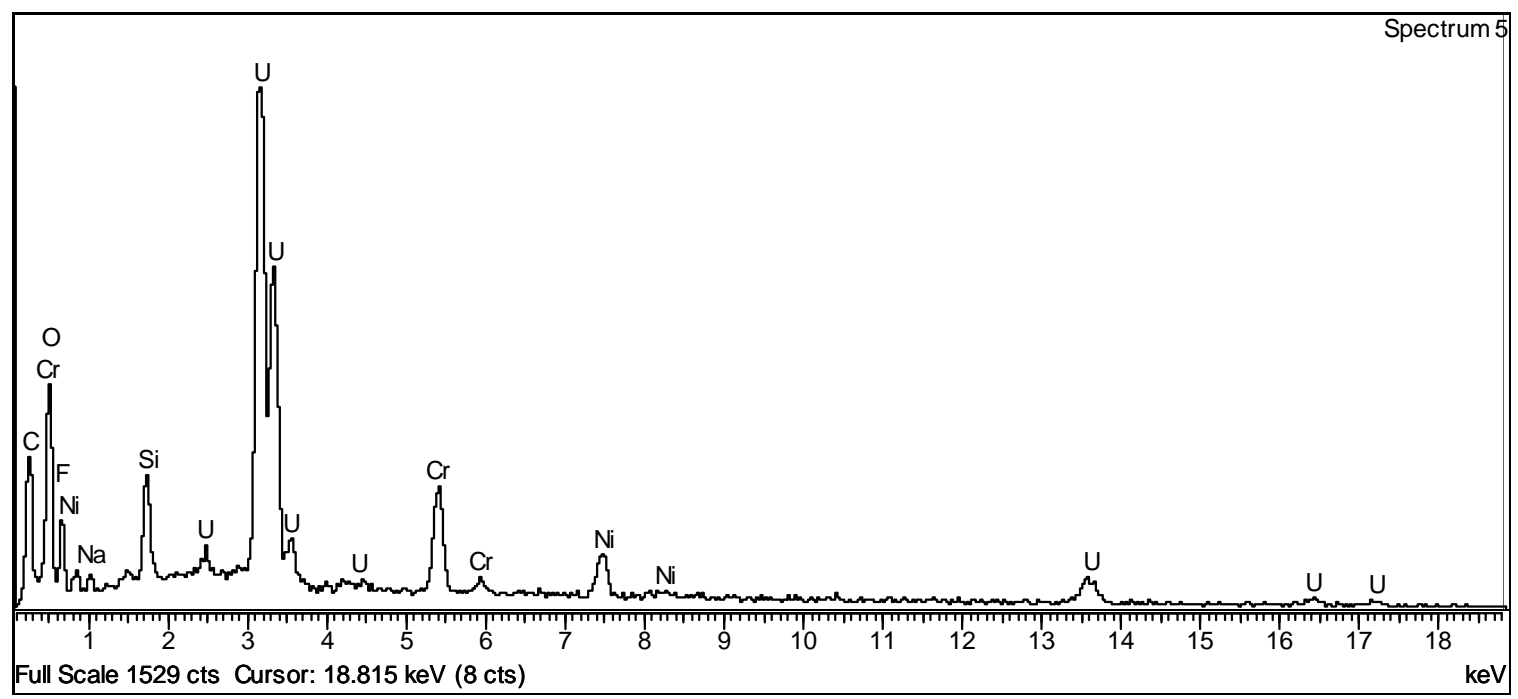

(e) Spectrum 5 (Spot 5)

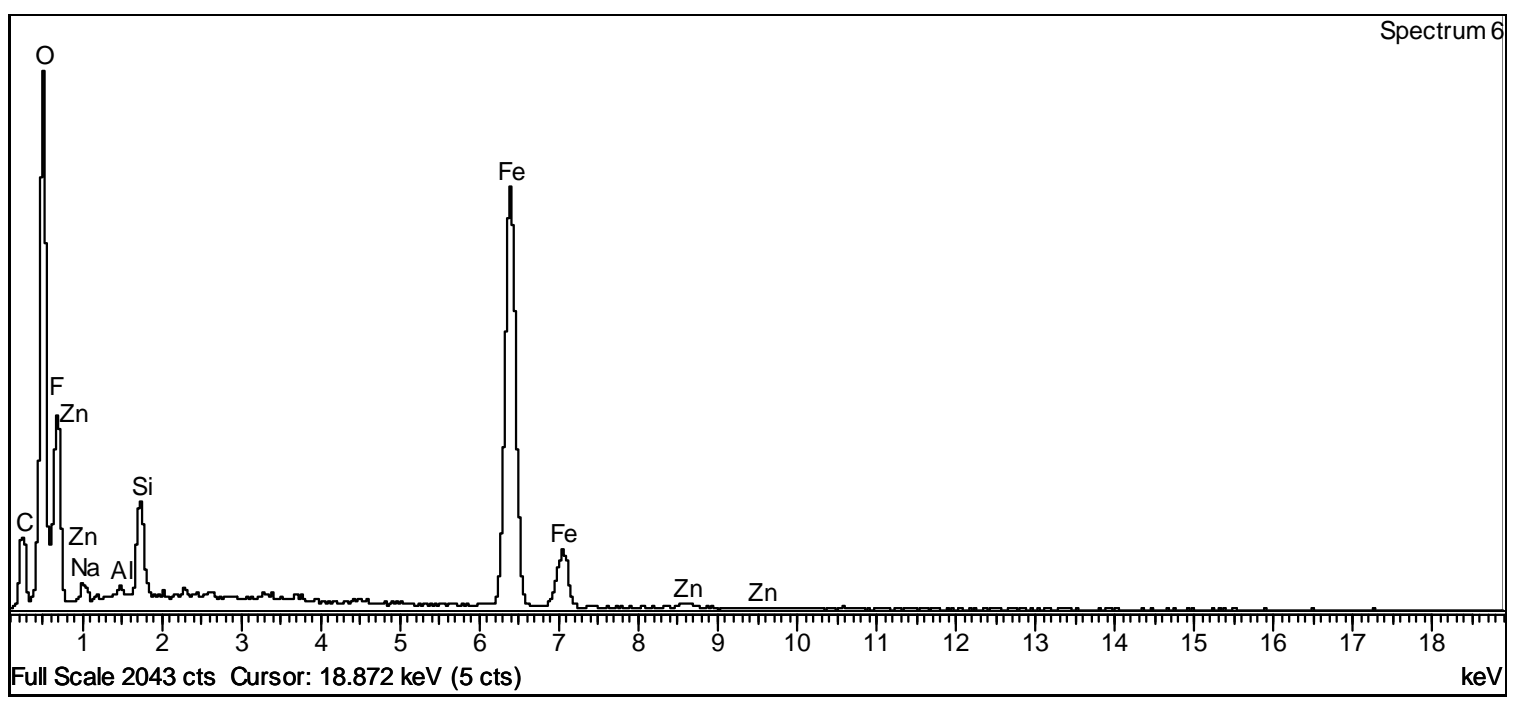

(f) Spectrum 6 (Spot 6) 
WSRC-TR-2005-00329

Revision 0

\section{This page was intentionally left blank.}


WSRC-TR-2005-00329

Revision 0

Figure 6 Continued

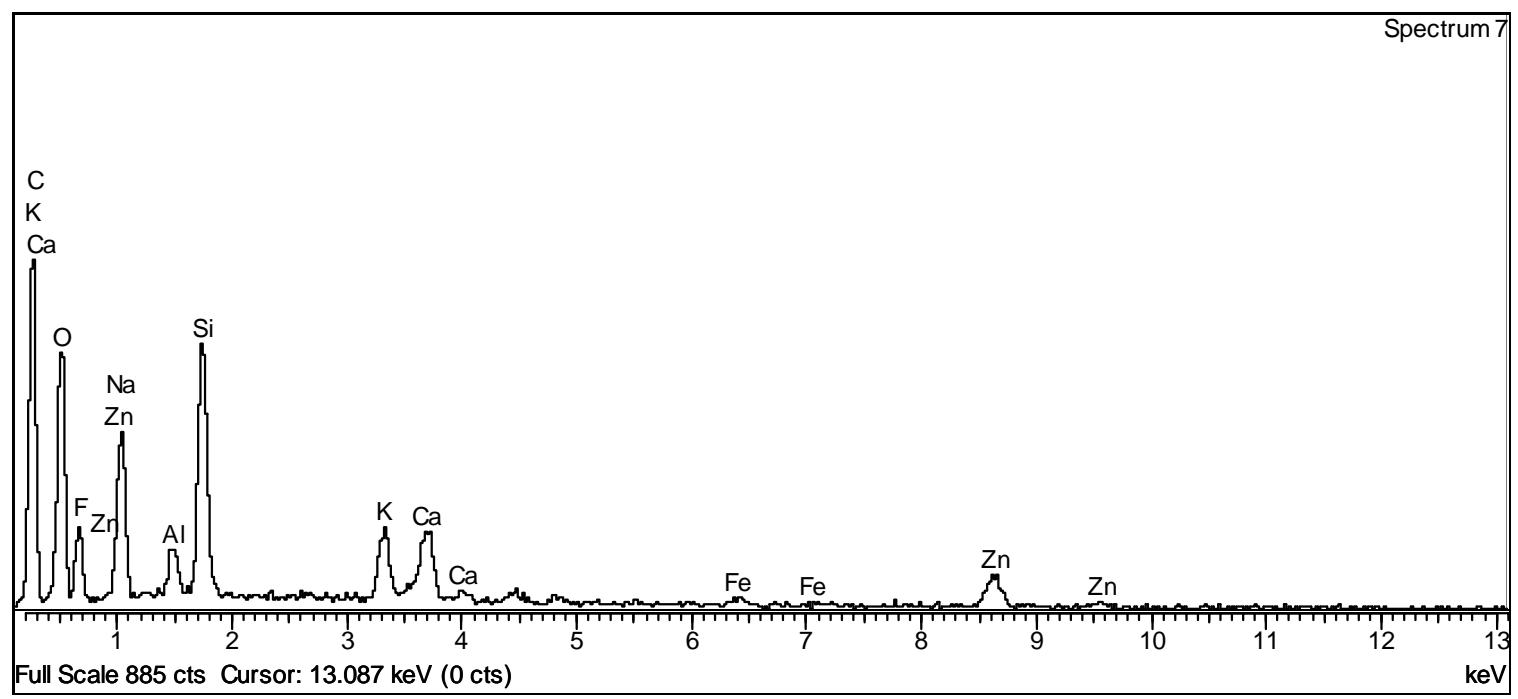

(g) Spectrum 7 (Spot 7)

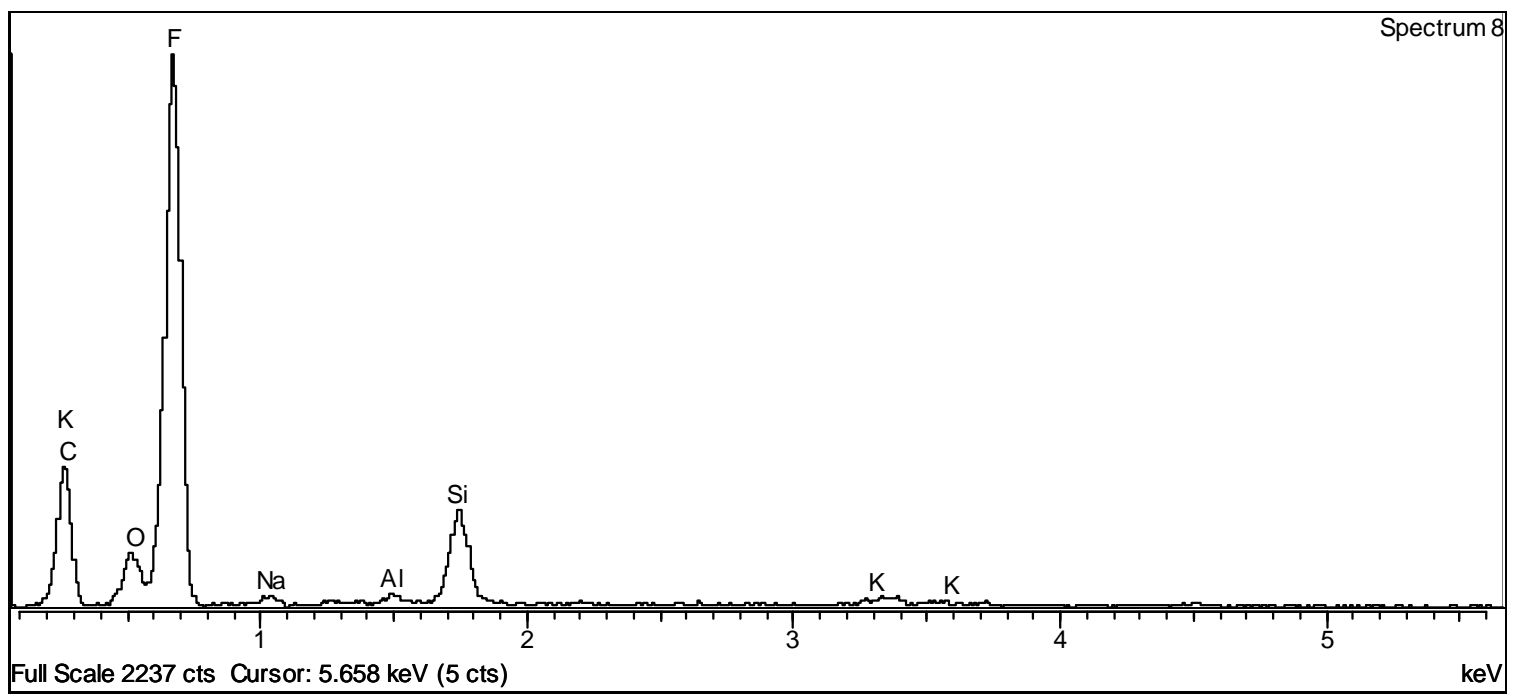

(h) Spectrum 8 (Spot 8) 
WSRC-TR-2005-00329

Revision 0

\section{This page was intentionally left blank.}




\section{Appendix A Elemental Analyses for Flowsheet Demonstration}

The radiochemical, ICP-ES, and IC analyses for the samples generated during the flowsheet demonstration are presented in Table A.1-A.3. Table A.1 includes the gross alpha activity determined by liquid scintillation counting and the ${ }^{241} \mathrm{Am}$ activity determined by GPHA. The $\mathrm{Pu}$ activity was calculated by subtracting the ${ }^{241} \mathrm{Am}$ activity from the gross alpha activity. The $\mathrm{Pu}$ concentration was then calculated using a specific activity of $1.6 \mathrm{E}+08 \mathrm{dpm} / \mathrm{mg}$ for weapons grade $\mathrm{Pu}$.

Table A.1 Radiochemical Analysis for Dissolver Samples

\begin{tabular}{ccccc}
\hline \hline Time & $\begin{array}{c}\text { Gross Alpha } \\
\text { Activity } \\
(\mathrm{dpm} / \mathrm{mL})\end{array}$ & $\begin{array}{c}{ }^{241} \mathrm{Am} \\
\text { Activity } \\
(\mathrm{dpm} / \mathrm{mL})\end{array}$ & $\begin{array}{c}\mathrm{Pu} \\
\text { Activity } \\
(\mathrm{dpm} / \mathrm{mL})\end{array}$ & $\begin{array}{c}\mathrm{Pu} \\
\text { Concentration } \\
(\mathrm{g} / \mathrm{L})\end{array}$ \\
\hline 1 & $1.73 \mathrm{E}+08$ & $1.16 \mathrm{E}+07$ & $1.61 \mathrm{E}+08$ & 1.01 \\
2 & $1.79 \mathrm{E}+08$ & $1.18 \mathrm{E}+07$ & $1.67 \mathrm{E}+08$ & 1.04 \\
3 & $1.76 \mathrm{E}+08$ & $1.19 \mathrm{E}+07$ & $1.64 \mathrm{E}+08$ & 1.03 \\
4 & $1.76 \mathrm{E}+08$ & $1.15 \mathrm{E}+07$ & $1.64 \mathrm{E}+08$ & 1.03 \\
5 & $1.77 \mathrm{E}+08$ & $1.14 \mathrm{E}+07$ & $1.66 \mathrm{E}+08$ & 1.04 \\
6 & $1.79 \mathrm{E}+08$ & $1.21 \mathrm{E}+07$ & $1.67 \mathrm{E}+08$ & 1.04 \\
7 & $1.78 \mathrm{E}+08$ & $1.19 \mathrm{E}+07$ & $1.66 \mathrm{E}+08$ & 1.04 \\
8 & $1.79 \mathrm{E}+08$ & $1.19 \mathrm{E}+07$ & $1.67 \mathrm{E}+08$ & 1.04 \\
\hline
\end{tabular}

The elemental analysis determined by ICP-ES is shown in Table A.2. The table gives the elemental concentrations for samples removed from the dissolver at one hour intervals. The sample designated as time zero was removed from the solution prior to the addition of $\mathrm{Pu}$ and Be. The concentration reported for strontium $(\mathrm{Sr})$ is biased high due to spectral interferences from $\mathrm{Pu}$; it should only be present as a trace impurity $(<10 \mathrm{mg} / \mathrm{L})$. In addition, the cerium $(\mathrm{Ce})$ concentration is probably biased high based on previous work.[5] The relatively high concentration of silicon $(\mathrm{Si})$ was attributed to corrosion of the glass dissolution vessel by the $\mathrm{F}^{-}$-containing solution.

The concentration of $\mathrm{F}^{-}$measured by IC is given in Table A.3. The table gives the concentrations for samples removed from the dissolver at $4 \mathrm{~h}$ intervals. The sample designated as time zero was removed from the solution prior to the addition of $\mathrm{Pu}$ and $\mathrm{Be}$. 
WSRC-TR-2005-00329

Revision 0

Table A.2 ICP-ES Analysis for Dissolver Samples

\begin{tabular}{|c|c|c|c|c|c|c|c|c|c|}
\hline \multirow[t]{2}{*}{ Element } & \multicolumn{9}{|c|}{ Elemental Concentration for Each Sample Time (h) } \\
\hline & $\begin{array}{c}0 \\
(\mathrm{mg} / \mathrm{L})\end{array}$ & $\begin{array}{c}1 \\
(\mathrm{mg} / \mathrm{L}) \\
\end{array}$ & $\begin{array}{c}2 \\
(\mathrm{mg} / \mathrm{L}) \\
\end{array}$ & $\begin{array}{c}3 \\
(\mathrm{mg} / \mathrm{L}) \\
\end{array}$ & $\begin{array}{c}4 \\
(\mathrm{mg} / \mathrm{L}) \\
\end{array}$ & $\begin{array}{c}5 \\
(\mathrm{mg} / \mathrm{L}) \\
\end{array}$ & $\begin{array}{c}6 \\
(\mathrm{mg} / \mathrm{L}) \\
\end{array}$ & $\begin{array}{c}7 \\
(\mathrm{mg} / \mathrm{L}) \\
\end{array}$ & $\begin{array}{c}8 \\
(\mathrm{mg} / \mathrm{L}) \\
\end{array}$ \\
\hline$\overline{\mathrm{Ag}}$ & $<1.10$ & $<1.10$ & $<1.10$ & $<1.10$ & $<1.10$ & $<1.10$ & $<1.10$ & $<1.10$ & $<1.10$ \\
\hline $\mathrm{Al}$ & $<4.20$ & $<4.20$ & $<4.20$ & $<4.20$ & $<4.20$ & $<4.20$ & $<4.20$ & $<4.20$ & $<4.20$ \\
\hline B & 2360 & 2380 & 2370 & 2390 & 2420 & 2390 & 2320 & 2390 & 2380 \\
\hline $\mathrm{Ba}$ & $<2.30$ & $<2.30$ & $<2.30$ & $<2.30$ & $<2.30$ & $<2.30$ & $<2.30$ & $<2.30$ & $<2.30$ \\
\hline $\mathrm{Be}$ & $<0.155$ & 116 & 117 & 118 & 121 & 122 & 116 & 121 & 118 \\
\hline $\mathrm{Ca}$ & 5260 & 5320 & 5240 & 5570 & 5390 & 5360 & 5190 & 5350 & 5310 \\
\hline $\mathrm{Cd}$ & 1.17 & 1.11 & 0.691 & 0.886 & 0.944 & 1.08 & 0.77 & 0.907 & 0.617 \\
\hline $\mathrm{Ce}$ & 18.5 & 35.1 & 35.4 & 33.1 & 36.4 & 41.2 & 36.5 & 30.1 & 33.6 \\
\hline $\mathrm{Cr}$ & $<2.60$ & $<2.60$ & $<2.60$ & $<2.60$ & $<2.60$ & $<2.60$ & $<2.60$ & $<2.60$ & $<2.60$ \\
\hline $\mathrm{Cu}$ & $<1.00$ & 2.09 & 1.95 & 2.15 & 2.23 & 2.12 & 1.94 & 2.04 & 1.97 \\
\hline $\mathrm{Fe}$ & 3820 & 3850 & 3810 & 3880 & 3900 & 3880 & 3750 & 3870 & 3840 \\
\hline $\mathrm{Gd}$ & $<1.70$ & 1.9 & 2.13 & 1.85 & 1.92 & 2.46 & 1.93 & 1.79 & 1.96 \\
\hline K & $<77.9$ & $<77.9$ & $<77.9$ & $<77.9$ & $<77.9$ & $<77.9$ & $<77.9$ & $<77.9$ & $<77.9$ \\
\hline $\mathrm{La}$ & $<5.20$ & 5.82 & 5.7 & 5.68 & 5.74 & 6.99 & 6.08 & 5.27 & 5.87 \\
\hline $\mathrm{Li}$ & $<4.80$ & $<4.80$ & $<4.80$ & $<4.80$ & $<4.80$ & $<4.80$ & $<4.80$ & $<4.80$ & $<4.80$ \\
\hline $\mathrm{Mg}$ & $<0.400$ & $<0.400$ & $<0.400$ & 13.5 & $<0.400$ & $<0.400$ & $<0.400$ & $<0.400$ & $<0.400$ \\
\hline $\mathrm{Mn}$ & $<0.200$ & $<0.200$ & $<0.200$ & $<0.200$ & $<0.200$ & $<0.200$ & $<0.200$ & $<0.200$ & $<0.200$ \\
\hline Mo & 20.2 & 24.2 & 20.1 & 24.8 & 23.8 & 25.3 & 21.8 & 22.8 & 28.4 \\
\hline $\mathrm{Na}$ & $<35.6$ & $<35.6$ & $<35.6$ & $<35.6$ & $<35.6$ & $<35.6$ & $<35.6$ & $<35.6$ & $<35.6$ \\
\hline $\mathrm{Ni}$ & $<4.00$ & $<4.00$ & $<4.00$ & $<4.00$ & $<4.00$ & $<4.00$ & $<4.00$ & $<4.00$ & $<4.00$ \\
\hline $\mathrm{P}$ & $<26.7$ & $<26.7$ & $<26.7$ & $<26.7$ & $<26.7$ & $<26.7$ & $<26.7$ & $<26.7$ & $<26.7$ \\
\hline $\mathrm{Pb}$ & $<76.1$ & $<76.1$ & $<76.1$ & $<76.1$ & $<76.1$ & $<76.1$ & $<76.1$ & $<76.1$ & $<76.1$ \\
\hline $\mathrm{S}$ & 9.47 & 13 & 13.6 & 16.5 & $<8.60$ & 14.9 & 10.1 & 56.9 & 13.2 \\
\hline $\mathrm{Sb}$ & 11.7 & 15 & 17 & 17.8 & 18 & 20.1 & 17.1 & 16.9 & 17.9 \\
\hline $\mathrm{Si}$ & 141 & 138 & 132 & 136 & 152 & 172 & 174 & 183 & 182 \\
\hline $\mathrm{Sn}$ & $<30.0$ & 30.9 & 38.1 & 34.5 & 40.8 & 30.8 & 30.3 & 32.9 & $<30.0$ \\
\hline $\mathrm{Sr}$ & 1040 & 1040 & 1030 & 1080 & 1060 & 1040 & 1020 & 1040 & 1030 \\
\hline $\mathrm{Ti}$ & $<0.300$ & $<0.300$ & $<0.300$ & $<0.300$ & $<0.300$ & $<0.300$ & $<0.300$ & $<0.300$ & $<0.300$ \\
\hline U & $<19.6$ & $<19.6$ & $<19.6$ & $<19.6$ & $<19.6$ & $<19.6$ & $<19.6$ & $<19.6$ & $<19.6$ \\
\hline V & $<2.00$ & 18.8 & $<2.00$ & $<2.00$ & $<2.00$ & 19.8 & $<2.00$ & $<2.00$ & $<2.00$ \\
\hline $\mathrm{Zn}$ & 0.729 & 2.51 & 2.78 & 9.85 & 8.17 & 3.11 & 2.36 & 2.66 & 3.35 \\
\hline $\mathrm{Zr}$ & $<0.800$ & $<0.800$ & $<0.800$ & $<0.800$ & $<0.800$ & $<0.800$ & $<0.800$ & $<0.800$ & $<0.800$ \\
\hline
\end{tabular}

Table A.3 F F $^{-}$Analysis for Dissolver Samples

\begin{tabular}{cc}
\hline \hline $\begin{array}{c}\text { Time } \\
(\mathrm{h})\end{array}$ & $\begin{array}{c}\text { Concentration } \\
(\mathrm{mg} / \mathrm{L})\end{array}$ \\
\hline 0 & 3520 \\
4 & 3700 \\
8 & 4000 \\
\hline
\end{tabular}




\section{Appendix B Correction of Elemental Concentrations for Changes in Volume}

The elemental concentrations in each of the samples were corrected for small changes in volume which occurred due to sample removal and evaporation losses from the dissolver. A small correction was also made for the material removed in samples prior to completing the experiment. The volume of the samples removed from the dissolver was $1 \mathrm{~mL}$ for each of the analyses performed. The evaporation rate was estimated from the initial and final dissolving solution volumes and the number of samples removed. The calculations are summarized in Table B.1.

Table B.1 Evaporation Rate During Pu/Be Dissolution Experiment

\begin{tabular}{ccccc}
\hline \hline $\begin{array}{c}\text { Initial Solution } \\
\text { Volume } \\
(\mathrm{mL})\end{array}$ & $\begin{array}{c}\text { Final Solution } \\
\text { Volume } \\
(\mathrm{mL})\end{array}$ & $\begin{array}{c}\text { Total Sample } \\
\text { Volume } \\
(\mathrm{mL})\end{array}$ & $\begin{array}{c}\text { Evaporated } \\
\text { Volume } \\
(\mathrm{mL})\end{array}$ & $\begin{array}{c}\text { Evaporation } \\
\text { Rate } \\
(\mathrm{mL} / \mathrm{hr})\end{array}$ \\
\hline 998 & 958 & 18 & 22 & 2.75 \\
\hline
\end{tabular}

(1) Two $1 \mathrm{~mL}$ samples were removed from the dissolver prior to the addition of Pu and Be metals.

The calculations in Table B.1 assume the evaporation rate was constant during the dissolving experiment and that no other losses of solution occurred. The volume of the samples removed at each sample time and the estimated volumes of solution in the dissolver prior to the removal of samples are given in Table B.2.

Table B.2 Sample and Estimated Dissolver Volumes

\begin{tabular}{ccc}
\hline \hline $\begin{array}{c}\text { Sample } \\
\text { Time } \\
(\mathrm{h})\end{array}$ & $\begin{array}{c}\text { Sample } \\
\text { Volume } \\
(\mathrm{mL})\end{array}$ & $\begin{array}{c}\text { Dissolver } \\
\text { Volume }^{(1)} \\
(\mathrm{mL})\end{array}$ \\
\hline 1 & 2 & 995 \\
2 & 2 & 991 \\
3 & 2 & 986 \\
4 & 3 & 980 \\
5 & 2 & 975 \\
6 & 2 & 971 \\
7 & 2 & 966 \\
8 & 3 & 960 \\
\hline (1) Volume
\end{tabular}

(1) Volume was estimated before sample removal.

The corrected concentrations for $\mathrm{Pu}, \mathrm{Be}, \mathrm{B}, \mathrm{Ca}$, and $\mathrm{Fe}$ were calculated by adjusting for the change in volume and accounting for the small amount of material removed from the dissolving solution in each sample. The generalized expression used to calculate the corrected concentrations at sample time $\mathrm{t}\left(\mathrm{C}_{\mathrm{t}^{\text {corrected }}}\right)$ is given as Equation B.1, 


$$
\mathrm{C}_{\mathrm{t}^{\text {corrected }}}=\frac{\mathrm{C}_{\mathrm{t}} \mathrm{V}_{\mathrm{t}}+\sum_{\mathrm{i}=1}^{\mathrm{t}-1} \mathrm{C}_{\mathrm{i}} \mathrm{Vs}_{\mathrm{i}}}{\mathrm{V}_{0}}
$$

where $C_{t}$ and $C_{i}$ are the measured concentrations (see Tables A.1-A.2), $V_{t}$ is the estimated volume (see Table B.2), $\mathrm{Vs}_{\mathrm{i}}$ is the sample volume (see Table B.2), and $\mathrm{V}_{0}$ is the initial volume $(998 \mathrm{~mL})$. The corrected concentrations for these elements are given in Table B.3.

Table B.3 Corrected Elemental Concentrations for Flowsheet Demonstration

\begin{tabular}{ccccccc}
\hline \hline $\begin{array}{c}\text { Time } \\
(\mathrm{h})\end{array}$ & $\begin{array}{c}\mathrm{Pu} \\
(\mathrm{g} / \mathrm{L})\end{array}$ & $\begin{array}{c}\mathrm{Be} \\
(\mathrm{g} / \mathrm{L})\end{array}$ & $\begin{array}{c}\mathrm{B} \\
(\mathrm{g} / \mathrm{l})\end{array}$ & $\begin{array}{c}\mathrm{Fe} \\
(\mathrm{g} / \mathrm{L})\end{array}$ & $\begin{array}{c}\mathrm{Ca} \\
(\mathrm{M})\end{array}$ & $\begin{array}{c}\mathrm{F}^{-} \\
(\mathrm{M})\end{array}$ \\
\hline 0 & 0 & $\mathrm{BDL}$ & 2.36 & 3.84 & 0.13 & 0.19 \\
1 & 1.01 & 0.12 & 2.37 & 3.79 & 0.13 & $\mathrm{NM}$ \\
2 & 1.04 & 0.12 & 2.36 & 3.85 & 0.14 & $\mathrm{NM}$ \\
3 & 1.02 & 0.12 & 2.37 & 3.85 & 0.13 & $\mathrm{NM}$ \\
4 & 1.02 & 0.12 & 2.39 & 3.83 & 0.13 & 0.19 \\
5 & 1.02 & 0.12 & 2.36 & 3.69 & 0.13 & $\mathrm{NM}$ \\
6 & 1.03 & 0.11 & 2.28 & 3.80 & 0.13 & $\mathrm{NM}$ \\
7 & 1.02 & 0.12 & 2.34 & 3.75 & 0.13 & $\mathrm{NM}$ \\
8 & 1.02 & 0.12 & 2.33 & 3.84 & 0.13 & 0.20 \\
\hline
\end{tabular}

$\mathrm{BDL} \equiv$ Below Detection Limit

$\mathrm{NM} \equiv$ Not Measured

Since the $\mathrm{F}^{-}$concentration was only measured at the beginning, middle, and end of the dissolution experiment, the measured concentrations were only corrected for changes in volume. The generalized expression used to calculate the corrected concentrations at sample time $t$ $\left(\mathrm{C}_{\mathrm{t}^{\text {corrected }}}\right)$ is given as Equation B.2,

$$
\mathrm{C}_{\mathrm{t}^{\text {corrected }}}=\frac{\mathrm{C}_{\mathrm{t}} \mathrm{V}_{\mathrm{t}}}{\mathrm{V}_{0}}
$$

where $C_{t}$ is the measured concentration (see Table A.3), $V_{t}$ is the estimated volume (see Table B.2), and $V_{0}$ is the initial volume $(998 \mathrm{~mL})$. The corrected concentrations for the three samples are given in Table B.3. 